\title{
Climate Change Patterns Affecting SMMES Business Sustainability in Buchbuckridge District Local Municipality, South Africa
}

\section{Evelyn Chiloane-Tsoka}

\author{
Professor, University of South Africa
}

chiloge@unisa.ac.za

Junior Mabiza-ma-Mabiza

University of Johannesburg

jmabiza@uj.ac.za

Doi:10.5901/ajis.2014.v3n6p109

\begin{abstract}
The Local Government in South Africa faces several strong developmental challenges. Although there are several interventions that are introduced to confront these challenges, which include mainly climate change, poverty, unemployment, skills shortage, illiteracy and health care including (HIVIAIDS) with partial success. In this paper, a conceptual framework is proposed for climate change and its impact on small, medium and micro enterprises (SMMEs) in particular those in agricultural sectors of Bushbuckridge in South Africa. Rural communities and local municipalities will need to find appropriate and efficient ways of developing resilience to climate change through adaptation measures. These measures will need to be supported at a systemic level, including through intergovernmental finance mechanisms. Therefore SMMEs need to adapt and mitigate climate change effects interacting with the sustainability of their business growth activities within Bushbuckridge Municipality area. In this article, a conceptual framework is proposed for small, medium and micro enterprises (SMMEs) in South Africa. The literature review includes an analysis of documents issued by Bushbuckridge local municipalities as well by the National Department of Provincial and Local Government. Finally the intended contextualised literature is for municipalities to develop strategies to assist SMMEs in agriculture.
\end{abstract}

Keywords: Climate change $\cdot$ SMMEs Sustainability · Adaptation · Mitigation · Agriculture $\cdot$ Local Economic Development Municipality of Limpopo

\section{Introduction}

Local economic development (LED) is a policy in South Africa for economic development that allows and encourages local people to work together to achieve sustainable economic growth and development. This policy is aimed at bringing economic benefits and improved quality of life to all residents in a local municipal area. Human, Marais and Botes (2008) view LED as a function of local government, in an economic sense, which is required to create viable conditions conducive to the success of business activities. As LED is to assist SMMEs, the success of Agriculture is embraced by playing a significant role in the country's economy. In 2012 the sector contributed about 2.57\% of GDP, 10\% formal employment and $10 \%$ of the total value of exports. However, global climate change have affected the government's efforts to alleviate poverty and fast-track development in rural areas. Beyond that, informal settlements in the majority of the local municipalities countrywide are vulnerable to environmental and health risks due to dwellings that are prone to disaster and lack of public basic services. The rural areas of the Bushbuckridge District of the Limpopo province are not exceptions to the rule of environmental health risk neither to the challenges brought by climate change impacts; these are the cause of a series of weather disturbances reducing crop harvest, poor crop quality, and land degradation. The current climate change is a difficult concept to understand given extremely difficult complex interactions between land, oceans and atmosphere, and uncertainties in trying to model and predict the outcome of these interactions, particularly at the local municipality levels. In addition the impacts of these changing global patterns are increased by poor natural resource management that negatively impact on operations of SMME's in the rural areas. Global food sustainability supply has been threatened already by climate change effects. Without any action taken by governments and municipality authorities this is only going to get worse. 


\section{The Phenomenon Climate Change}

The phenomenon "climate change" refers to a continuing trend of changes in the earth's global weather conditions as a result of an average rise in the temperature of the earth's surface often referred to as global warming. At present the global climate is changing much more rapidly as a result of global warming, leading to, among others, the melting of polar and glacier ice, sea-level rise, ocean acidification, changes in snowfall and rainfall patterns, more frequent floods and droughts and increased frequency and intensity of extreme weather events. The rapid rate of this climate change does not allow the earth's bio-physical systems to adapt to these changes naturally (Parry et al. 2007). Climate change is the imbalanced ecological systems equilibrium disturbed by human activities.

\section{Historic Overview of Bushbuckridge District Municipality}

The Bushbuckridge district municipality is located in the north of South Africa and is not only affected by climate change but also challenged by scarcity of water supply. Bushbuckridge is historical emerged from the former homeland governments that were segregated by the apartheid policies of Bantu stand. The district is further stricken by poverty HIVIAids, and high illiteracy levels that are common to most poverty pockets of the Limpopo province. The communities are settled on what was designed for farmers without changing their land use. These unrecognised human settlements have high population density that has resulted in lack of service delivery for basic services by the local municipality (Masuku 2012). In his argument Masuku (2012) mentions that the available infrastructure was mostly prioritised for agricultural purposes and the system has since been overburdened by the growing human settlements and demand for water consumption. Thus, as an interim measure to address the challenges of water shortages the municipality is supplying the affected communities with water using water tankers. Deplorable is to observe that communities on the other hand, below par power supply, proceeds to illegal connections, acts of vandalism, as well as theft of transformers; all these also significantly contributing to the difficulties of supplying water to some areas of the district.

Above and beyond the precedent setbacks to the municipality, Mashele (2011) asserts that the devastating rising effects of climate change are aggravating the challenges affecting Bushbuckridge local municipalities. These impediments had therefore provided to the Bushbuckridge local municipalities a platform to resolve and review the bylaws governing sand mining, deforestation and bush fires. In his view, Mashele (2011) lamented the mitigation of the phenomena by holding a climate change road show to educate rural communities about the effects of the environmental change patterns and how to adapt to it. He pointed out that the climate change was a global challenge and people should be prepared to address the impacts of its effects. Mabuza (2011) conquered with the statement that South African weather patterns show up an unprecedented variability increases annually in temperatures, rain fall, floods and soil erosion.

Government regards climate change as a major challenge to the nation and added that communities needed to be educated to better understand the fundamentals of climate change. Bushbuckridge local municipalities had put measures in place such as programmes to educate the community in mitigating the impacts of the climate change by putting in place infrastructure and policies to assist SMMEs in matters affecting business that emanate due to climate change. Sibuyi (2011) pointed out that the municipality and the Department of environmental affairs were to engage traditional leaders to spread the message of veld fires and cutting of trees as trees assist in the intake and transformation of carbon dioxide, as well as the importance of recycling. Majority of rural residents cut trees down because they need the wood, for cooking and warming themselves during winter but not for the purpose of destroying nature. Unless alternatives of energy supply may take place, residents will not stop cutting trees. This challenge is embedded to local municipalities, the province, and to government at large.

\section{SMMEs in Agriculture, Climate Change and Basic Services Deliveries}

SMMEs involved in agriculture are confronted with challenges imposed by climate change impacts on their daily activities as they pursue to grow their business and are seriously impacted by basic service deliveries such as lack of sanitation, road infrastructure, insufficient energy supply, and water shortages. Emergence of climate change is further worsening by the inadaptability of solving the current issues faced.

There is therefore a need for SMMEs to mitigate and adapt to environmental challenges. Mitigation calls for developing the capacity to thwart and lessen greenhouse gas (GHG) emissions contributing to climate change effects with impacts on SMMEs activities in their persuasive efforts to business growth. Whereas adaptation calls for putting 
measures in place against climate change impacts befalling that are beyond capacity control. For SMMEs activities to be sustained there is a strong need to understand environmental disturbances in interaction with these activities. Environmental or ecological sustainability, one of the three legs of sustainability is as important as economic and social components. Awareness of environmental sustainability has become more of a concern because of the inability of the current ecology system to naturally address the effects of climate change and disturbances (Mabiza 2013). The involvement of environmental report on SMMEs, especially those operating in agriculture, is justified given the constraint regarding the land conditions, central to agricultural activity, caused by disturbances to the ecosystem.

Many studies have been conducted on how to tackle climate change effects interfering with human activities. Effects of climate change challenges interact with social and economic challenges resulting to incapability to offset climate change effects, Figure 2 on page 10, are as a result of direct and indirect primary climate change impacts and secondary impacts on SMMEs such skills shortages, incubators, financial collaterals, strategic policies, and lack of information dissemination. Social and economic challenges such as economic shocks and stresses, high level of poverty, scarce of natural resources each interact with climate change. While these challenges unfold and threaten SMMEs, future climate trends are uncertain and the uncertainty rises steeply over the longer-term.

Effects of climate change are not solely confronted the manner in which they occur, but also and unfortunately, they reinforce social and economic pressures on communities and SMMEs in their existing community entities to hinder the adequacy of their growth and development.

Parry et al. (2007) alluded that some municipalities will be more sensitive to these changes than others, and many municipalities may not have the capacity to adapt due to existing developmental challenges. These include low incomes, weak institutions, low levels of education and primary healthcare, lack of markets and infrastructure, and alreadydegraded ecosystems. Local municipalities in concert with government at large are to rescue and strengthen SMMEs development activities in order to ensure service delivery and to tackle climate change effects in Bushbuckridge of the greater north of Limpopo.

\section{Existing Research - Background}

The fact that $40 \%$ of South African live in rural areas, people are poor and mainly reliant on urban remittances and social development for their survival. Farming and agriculture is seen as the beacon of hope. While $70 \%$ of the country's poorest household live on small-scale farms and few of them produce enough food to feed themselves throughout the year (White Paper 2011). Beyond that, informal settlements are vulnerable to environmental and health risks due to dwellings that are prone to disaster and lack of basic services. Bushbuckridge rural areas are not exceptions to the rule of rural settlement. In South Africa, the current climate change is a difficult concept to understand given extremely difficult complex interactions between land, oceans and atmosphere, and uncertainties in trying to model and predict the outcome of these interactions, particularly at the local municipality levels. In addition the impacts of these changing global patterns are increased by poor natural resource management that negatively impact on operations of SMME's in the rural areas. Global food sustainability supply has been threatened already by climate change effects. Without any action taken by governments and municipality authorities this is only going to get worse.

Thus, the effects of the global climate change are regarded as critical and of greatest environmental challenge facing the operations of SMMEs operating in the rural areas as well. According to Odeku (2012), several governments came together in 1988 and formed the International Panel on Climate Change (IPCC) as a global response concerning all these challenges facing the world. These challenges are posing a major threat to atmospheric resources, resulting in climatic variations that have effects at multiple scales - temporal and spatial wherein, they are closely linked to global patterns of energy consumption and production. Furthermore, the impacts of these changing global patterns are increased by poor natural resource management that negatively impact on operations of SMME's in the rural areas.( United Nations Environment Programme 2007).

In addition a study conducted by Davies (2010) alluded that change of climate is attributed directly or indirectly to human activity that alters the composition of the global atmosphere in which natural climate variability observed over comparable time periods decay. Extreme weather conditions such as droughts and heavy rains affect agricultural productivity and parts of staple foods that are important for poor households in developing countries are destroyed, resulting in higher prices for consumers and decrease in the income of farmers (Odeku 2012).

Global food sustainability supply has been threatened already by climate change effects. Without any action taken by authorities this is only going to get worse. The impact of the above discourse on climate change has more negative imperatives in relations to SMMEs. SMMEs are faced with very severe structural constraints in terms of access to 
finance, technical capacity, and business experience, they are often characterised by a lack of competitiveness. This real or even perceived lack of competitiveness (i.e. ability to produce quality goods/services, consistently and on time) makes it all the more difficult for emerging entrepreneurs to establish or grow their businesses (BLM 2012). In order for SMME's to be competitive there is a need for adaptive and mitigation strategies given the diverse range of issues and considering the role of uncertainty around SMME's development with respect to planning, funding, incubating, monitoring and climate change among others, it is unlikely that the SMMEs in Mpumalanga and Limpopo can develop a comprehensive support strategy taking into consideration the complexity of the confronted aspects.

While global climate change is already a factual measurable, emerging countries such as South Africa, are trying to lay down transition to a climate-resilient, equitable and internationally competitive lower-carbon economy and society. Objectively to the South African perspective, the climate-resilient transition will have concurrently to address the country's national priorities for sustainable development, job creation, improved public and environmental health, poverty eradication, and social equality (White paper 2011). In this regard, South Africa intends to:

- Effectively manage inevitable climate change impacts through interventions that build and sustain South Africa's social, economic and environmental resilience and emergency response capacity.

- Make a fair contribution to the global effort to stabilise greenhouse gas (GHG) concentrations in the atmosphere at a level that avoids dangerous anthropogenic interference with the climate system within a timeframe that enables economic, social and environmental development to proceed in a sustainable manner.

Climate change in South Africa is expected to result in higher temperatures, more sporadic rainfall patterns and frequent droughts. Superimposed on the country's already scarce water resources, these impacts are expected to affect all sectors of the economy. The poor are disproportionately affected, as they rely on sectors that will be directly affected by climate change: agriculture, biodiversity, ecosystems and water supplies (Parry et al. 2007).

As the impacts of climate change will be localised, local institutions and governance will be the most important drivers of adaptation and coping mechanisms. However, since resources are limited, knowing which actions to prioritise is important so that the most vulnerable areas can be targeted. It is important to look at the South African municipalities that are most vulnerable to future climate change, as a basis for prioritising strategic interventions aimed at increasing resilience (Figure.1).

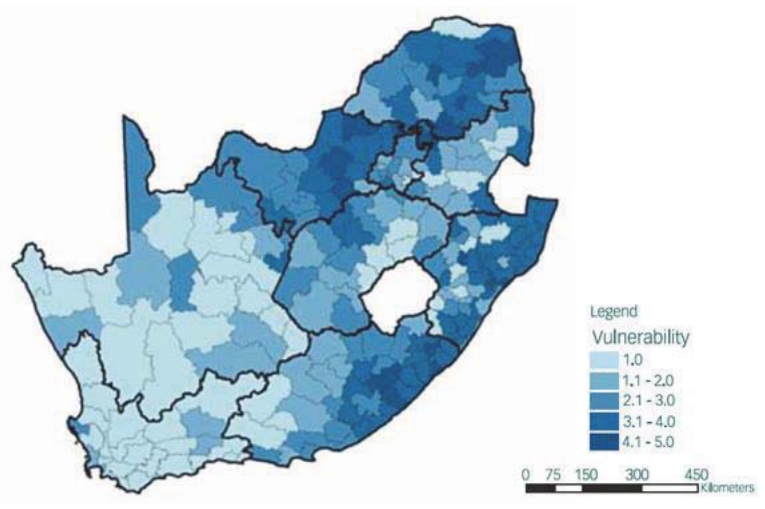

Figure1. Index value of vulnerability to climate for South African municipalities (Source: Parry et al. 2007)

Responses to climate change have been commonly categorised as either aimed at reducing the rate at which climate is changing to levels that occur naturally, and especially reducing the atmospheric concentrations of GHGs, also called mitigation; or responding to the adverse effects of climate change, the act is known as adaptation.

A key feature of adaptation responses is that they have a much stronger local context than do mitigation responses and their benefits may appear much faster and are often more tangible, such as an improvement in local environmental quality, for instance. Effective adaptation responses can also potentially create many jobs, particularly "green jobs", and could contribute significantly to sustainable development goals. Well planned adaptation responses can thus be effectively integrated with sustainable development policies.

Effective planning and coordination of an integrated adaptation response will require:

- Early warning and forecasting for disaster risk reduction.

- Medium-term (decade-scale) climate forecasting to identify potential resource challenges well in advance.

- Long-term climate projections that define the range of future climate conditions. 
At the national and local levels, the South African government has been active in generating strategies, policies and plans that respond to a growing awareness of the impacts of climate change. The National Climate Change Response White Paper (2011), principally, identifies different vulnerable groups (UNICEF 2011). In that, developing countries are particularly vulnerable to the impacts of climates because of their high dependence on natural resources and limited capacity to cope with these impacts while SMMEs are dependable mostly to these natural resource activities such as agriculture, farming for survival.

The intervention of the Local Economic Development within the local municipalities of the provinces Mpumalanga and Limpopo provide key strategic areas that are critical in order to aid the growth of SMMEs. The intervention of these strategies is outlined as referred by BLM report (2011) as follows:

- Private Sector Investment (CPPs in agriculture, tourism and forestry) which generates jobs, revenues and SMME opportunities

- Public Sector Investment (Infrastructure and PPPs) which generate jobs and SMME opportunities, complementing investments for LED

- Small and Micro Enterprises (which are stimulated by either private or public investments as well as pure entrepreneurial endeavour within the 34 wards) generating revenues and jobs

- Right to Work Programs (CWP) generating jobs

- There is a clear emphasis on the link between investment and jobs with employment being the key indicator in this regard. There is also interrelatedness amongst the four growth areas.

This research aims to focus on how SMMEs interact with effects of climate change and what efforts in terms of strategies on adaptation and mitigation can be put in place to alleviate these challenges in order to grow their business despite constraints they face of climate change impacts as well as how the local municipality respond to these challenges and assist the SMMEs sector operating in agriculture.

\subsection{Land Degradation}

The term land degradation describes a process. When something is degraded, its character is changed for the worse damage is done. This sounds serious, and it is never more than when it refers to the earth. Much land is covered with a thin crust of soil (or earth) that has taken many thousands of years to form. A great deal of life on the planet including human life depends on it. But it is very vulnerable, and once lost or damaged, it is extremely difficult, sometimes impossible, to put back. The most extreme evidence of land degradation is desert. The process of loss is often called soil erosion. When this happens, the structure of the soil and also sometimes the underlying shape or structure of the land is damaged (for example, through mining or quarrying). The plants and animals that live on the land are also harmed, or even wiped out. Land degradation can happen on a local scale, or over vast areas. Deserts are currently spreading at an alarming rate in dry areas around the world. Land degradation has been happening for millions of years. Some major deserts existed before human activities made any impact but the accelerated soil erosion taking place today is always as a result of human activities (Veld \& Flora 2010).

\subsection{Effects of land degradation}

When land is degraded, wildlife, plans and people suffer. It can worsen the effects of poverty and bring about hunger. Degradation of land has serious consequences for food security. Many small scale farmers in areas of degraded land can only watch in dismay as their soil grows less each year to feed their families. This situation is made worse by droughts and unpredictable weather patterns caused by climate change (Birdlife South Africa 2010). 


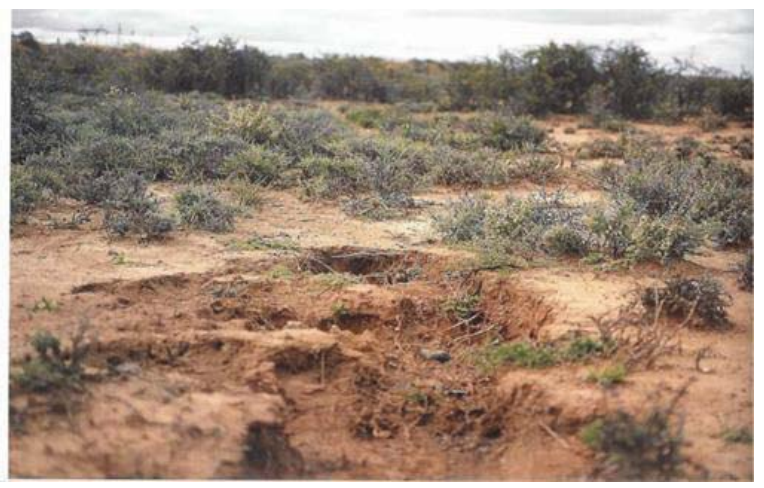

Figure 2: Start of Erosion on Patch of Over Grazed Land.

Source: (Msangi, 2011)

The process of land degradation in South Africa is blamed on water and wind erosion, sedimentation, long-term destruction of vegetation and diminution of the bio-resources. External forces including the state of the global economy, inaccessible markets and unfavourable commodity prices, the debt burden, unequal terms of trade and protectionism plus import barriers in developed countries may increase rates of natural resource exploitation by preventing diversification. Population pressure and human activities such as over-cultivation which exhausts the soil, overgrazing which removes the vegetation cover that protects soil from erosion, deforestation which removes trees and vegetation which binds the soil to the land and poorly designed irrigation that turn cropland saline. In most of the countries, inadequate budgetary allocations and lack of or poorly articulated regulations on implementation of the policies and coordination remain the greatest challenges facing these policies. Others include inadequate capacity to enforce these policies as well as lack of commitment and political will.

\subsection{The Bushbuckridge Municipal Strategy Approach}

The following form the Bushbuckridge municipal strategy approach:

- The Bushbuckridge is guided by the Municipal Systems Act 32 of 2000 wherein the strategy seeks to address the communication needs of the municipality by ensuring that information dissemination is encouraged and disseminated to SMMEs.

- The significance of communicating government programmes to SMMEs communities in and around Bushbuckridge and District stakeholders is on information about the necessity of incubators where SMMEs can visit for purposes of advice.

- Make available mechanisms, processes and procedures to encourage and facilitate community participation and access to training by SEDA and collaterals for funding

- Encourage and create conditions for SMMEs to participate in the affairs of the municipality and when training takes place for SMMEs regarding matters of agriculture, soil erosion, and land over gracing as well as land mine crop fertilisation.

\subsection{The objectives of the Bushbuckridge Municipal Strategy Approach}

The following are the municipality strategy approach-based objectives:

- Encourage public participation in government process and policies;

- Encourage communication between the municipality and sector departments;

- Including amongst others community based organizations, the Traditional Authorities and other important stakeholders;

- Co-ordination of government programmes National, Provincial, Local and parastatal through InterGovernmental Relation's framework communications;

- Develop and maintain correct public perception on Government services;

- Maintain good relations with the media by forging good relations; 
- Publicize the Bushbuckridge Local Municipality's programme of action (POA) as advised by the Executive Mayor.

The Bushbuckridge Local Municipalities have a number of challenges which form part of the priorities issues to look at in the medium term and certainly to the long term development strategy as well. These are, high poverty levels, crime, high illiteracy, HIVIAIDS epidemics, Unemployment, Back log of service delivery, and skills shortage.

\section{Gap in Research}

Traditional disparity studies should be consolidate and channelled toward an model approach that can provide a windows through which climate change effects, both primary and secondary befalling SMMEs, and the holistic challenges of SMMEs development per se. The following model developed (Figure 2) represents the comprehensive framework to the investigation approach which reflects the understanding and interaction between primary impacts and secondary impacts from climate change, and SMMEs holistic challenges.

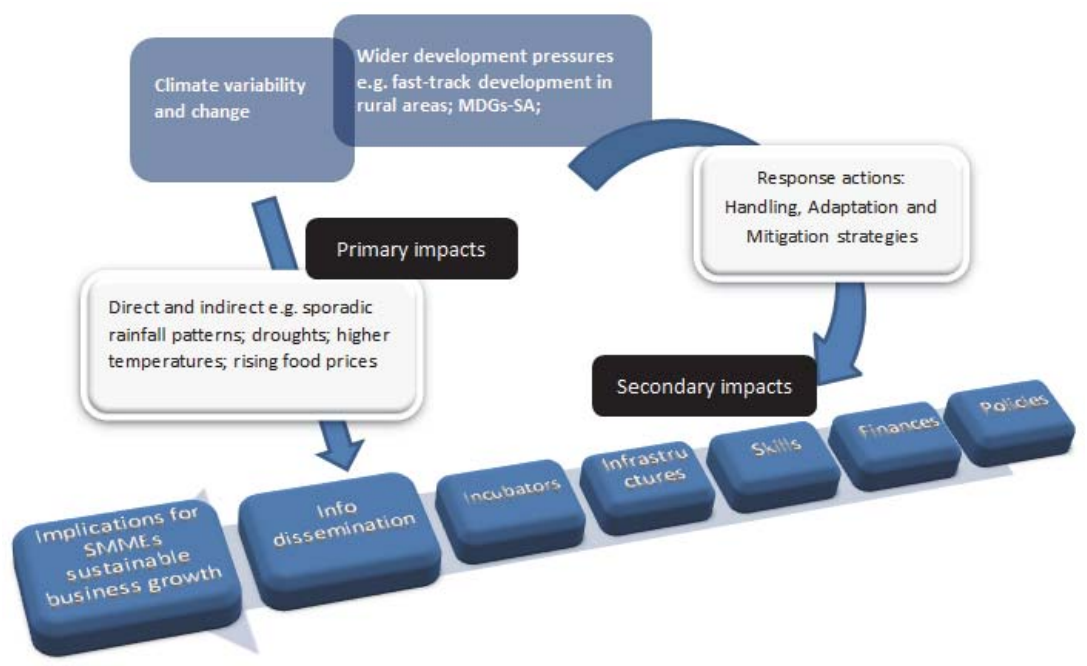

Figure 3: Investigative research approach framework for SMMEs, holistic challenges, and climate change impacts challenges

\section{Recommendations on the Mitigation of the Effects of Climate Change in the Local Municipalities of Bushbuckridge}

- The municipality need to increase people's awareness interest on protecting the environment by involving them directly in the process by reducing the incidence of poverty to reduce the pressure on natural resources and instil to people how a high level of resource use can go hand-in-hand with the maintenance of environmental quality.

- The Municipality can play an important role in promoting sustainable development and improving the environment by setting the correct investment priorities and provide needed infrastructure, services, education. Assist SMMEs providing safe water, collecting and disposing solid waste, and improving the infrastructure. Focus should be on health, education, and basic sanitation in other words urgent basic services for the present and future in Bushbuckridge population is a necessity.

- The government and municipality together with private sector initiative should set environmental standards that are realistic in terms of the district particular socioeconomic circumstances. For example, setting strict standards for indoor air pollution when most people cannot afford less-polluting energy sources simply makes enforcement impossible.

Provide regulatory measures aimed at removing those distortions in the economy that tend to penalize producers or promote overconsumption. Important examples include under-pricing agricultural commodities and subsidizing public goods and services, both of which favour the farmers and SMMEs respectively. 


\section{Conclusion}

Effective on rural migration exodus, can be expected to have not only direct impacts on rural communities in sort of reduced income and unemployment, but also knock-on effects for rural economies as a whole. This may put considerable strain on rural local governments, which provide services and promote development at a local level. Local municipalities will therefore need to plan and adapt absorbing climate impacts models. The burden on municipalities will increase because of the expected increases in natural disasters, water scarcity and disease, and reduced agricultural production and food security. Rural communities and local municipalities will need to find appropriate and efficient ways of developing resilience to climate change through adaptation measures. These measures will need to be supported at a systemic level, including through intergovernmental finance mechanisms.

Climate change is happening and will carry on. South African governments have put little efforts to oppose the climate adverse to agriculture in the more remote parts of countries and to climate-related migration consequently. Urgent measures on policy action and strategies to reduce climate-related migration are to be attended to urgently. In this way, development efforts and programs to reduce poverty will lessen livelihood vulnerability, ultimately reducing the need for families to migrate because of climate change.

\section{References}

Birdlife South Africa. (2010). Learning about Biodiversity. Veld \& Flora, 10: 175-177.

City of uMhlathuze, Local Economic Development Strategy, 2008-2011, South Africa.

Department of Provincial and Local Government 2002/3, South Africa.

Department of Provincial and Local Government. 2006, South Africa.

Department of Provincial and Local Government, Stimulating \& Developing. (2006). Sustainable Local Economies: National Framework for Local Economic Development in South Africa, Pretoria.

Davis, C. (2010). A climate change handbook for North-Eastern South Africa. Climate Change Research Group, Council for Scientific and Industrial Research (CSIR), Pretoria.

Human, F.; Marais, L. \& Botes, L. (2008). Measuring what? The utilization of development indicators in the integrated Development Planning process. Journal of Public Administration, 43 (3): 376-400.

Mabiza, M.J. (2013). Energy Potential and Sustainability Management of Platinum Catalyzed Fuel Cell Technology in South Africa. Dissertation, University of Johannesburg.

Mabuza, D. (2011). Climate change Road show. Bushbuckridge Municipality. http://www.thenewage.co.za/mobi/Detail.aspx?NewsID= 24141\&CatID=1014._Accessed 12 April 2014

Mashele, E. (2011). Climate change Road show. Bushbuckridge Municipality. http://www.thenewage.co.za/mobi/Detail.aspx?NewsID= 24141\&CatID=1014 Accessed 07 April 2014

Masuku, M. (2012). Government addressing water problems in Bushbuckridge Local Municipality. Rainwater harvesting for irrigation purposes: South Africa

Odeku, K. (2012). Strategies to overcome poverty \& inequality. Conference "Towards Carnegie III" University of Cape Town, 3-7 September.

Encyclopaedia of Earth. Eds. Environmental Information Coalition, National Council for Science and the Environment. Washington, D.C.

Parry M.L., Canziani, O.F., Palutikof, P.J., Van der Linden and Hanson, C.E. (2007). Climate Change: Impacts, Adaptation and Vulnerability. Contribution of Working Group II to the Fourth Assessment Report of the Intergovernmental Panel on Climate Change, pp 982, Cambridge University Press, Cambridge, UK.

Sibuyi, F. (2011) Climate change Road show. Bushbuckridge Municipality. http://www.thenewage.co.za/mobi/Detail.aspx?NewsID= 24141\&CatID=1014. Accessed 08 April 2014

United Nations Environment Programme. (2007) Environmental change and socioeconomic factors in Africa. In Encyclopaedia of Earth, Cleveland CJ (ed.). Environmental Information Coalition, National Council for Science and the Environment: Washington, DC. 